\title{
LABORATORY STUDIES ON THE USE OF A NEMATODE PHASMARHABDITIS HERMAPHRODITA (SCHNEIDER) IN SLUG CONTROL
}

\author{
EWA DANKOWSKA
}

\begin{abstract}
Chair of Plant Protection Methods, Agricultural University, Zgorzelecka 4, 60-198 Poznań, Poland (e-mail: kmor@post.pl)
\end{abstract}

ABSTRACT: Slugs Deroceras reticulatum (O. F. Müll.), Deroceras laeve (O. F. Müll.) and Lehmannia valentiana (Fér.) were tested for their susceptibility to infection with a nematode Phasmarhabditis hermaphrodita (Schneider). D. reticulatum was the most susceptible, $D$. laeve much less so, while $L$. valentiana was not attacked by the parasite. Ph. hermaphrodita may be used for slug control, but not all slug species are equally susceptible.

KEY WORDS: pests, slugs, slug control, nematodes, Phasmarhabditis hermaphrodita

\section{INTRODUCTION}

Slugs are among serious pests of greenhouse and field crops. Their mass occurrence may lead to complete destruction of plants, all parts of which get damaged. Slug control is difficult and there are practically no effective control means (DANKOWSKA 1991, 1996, DANKOWSKA \& BARANOWSKI 1998).

One way of biological plant protection is using a parasitic nematode Phasmarhabditis hermaphrodita (Nematoda: Rhabditidae) - vector of mutualistic gram-negative bacteria Moraxella osloensis (TAN \& GREWAL 2001) which are deleterious to slugs. Invasive forms of the nematode penetrate the slug body through its natural orifices, the bacteria are released, quickly multiply and cause a slow death of the gastropod. Three to five days from the nematode invasion the slugs stop feeding, and in one or two weeks they die. The nematodes, which have multiplied inside the slug, leave its body and actively seek a new host. The first characteristic symptom of nematode invasion is swelling of the slug mantle (WILSON et al. 1993, 1994; BLANKE 1995, DANKOWSKA 1998).

This study was aimed at testing, in laboratory experiments, the susceptibility of three slug species to infection with Phasmarhabditis hermaphrodita.

\section{MATERIAL AND METHODS}

Laboratory experiments aimed at testing the nematode Phasmarhabditis hermaphrodita (Schneider) as a means of slug control were conducted in the Chair of Plant Protection Methods, Agricultural University, Poznań. They consisted of two stages. In both a British biopreparation NemaSlug was used, containing invasive forms of Phasmarhabditis hermaphrodita in a special medium.

In the first experiment the slugs were kept in Petri dishes of $10 \mathrm{~cm}$ diameter, lined with a few layers of fil- ter paper. The slugs used were Deroceras laeve (O. F. Müller, 1774), Deroceras reticulatum (O. F. Müller, 1774) and Lehmannia valentiana (Férussac, 1823). The experiment was run in five replicates, using separately five slugs for each replicate. One gram of NemaSlug was dissolved in $200 \mathrm{ml}$ distilled water, resulting in a uniform suspension of nematodes. Five ml of the suspension (ca. 8,000 nematodes) were taken and $1 \mathrm{ml}$ was dripped directly on each slug. In the control only distilled water was dripped onto the slugs. 
The second experiment was to test if the nematodes could actively find and infest the slugs. It was conducted in plastic containers $(15 \times 8 \times 7 \mathrm{~cm})$, filled with a $1 \mathrm{~cm}$ layer of humid soil. The experiment was run in five replicates. The soil in each container, prior to placing the slugs on it, was sprinkled with $5 \mathrm{ml} \mathrm{ne-}$ matode suspension, and then 5 slugs Deroceras reticulatum, Deroceras laeve and Lehmannia valentiana were placed there separately. Only distilled water was used in control containers. After five days the slugs were transferred to Petri dishes, $10 \mathrm{~cm}$ diameter, lined with a few layers of humid filter paper.

In both experiments the slugs were fed oat flakes. The experiments lasted two weeks during which behaviour and appearance of the slugs were recorded, dead slugs counted, and then mortality for each species was calculated.

\section{RESULTS AND DISCUSSION}

The results of the first experiment (direct placing of the nematodes on the slug bodies) are presented in Fig. 1. D. reticulatum was the most susceptible to infection with Phasmarhabditis hermaphrodita $(60 \%$ mortality). D. laeve was also killed by the nematodes, but the mortality was much lower (16\%). L. valentiana was not susceptible to the nematode invasion.

The results of the second experiment are presented in Fig. 2. The nematodes released in the soil were capable of finding the slugs and killing them.

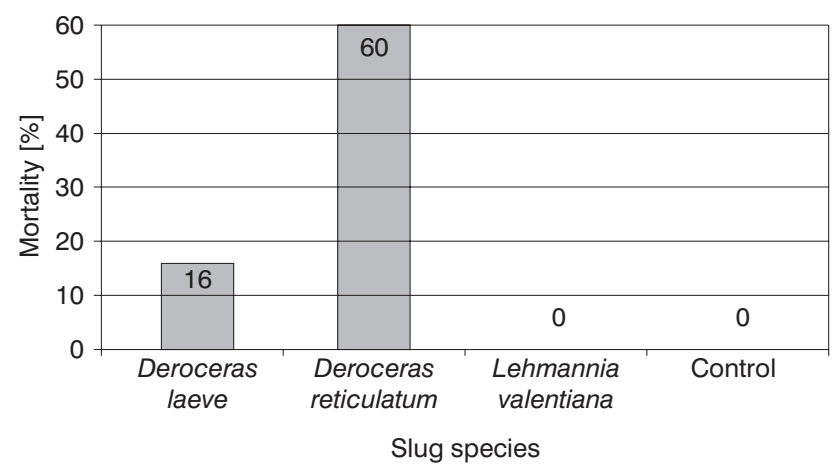

Fig. 1. The effect of Phasmarhabditis hermaphrodita applied directly (experiment I) on the slug mortality

\section{REFERENCES}

BLANKE M. 1995. Nematoden gehen auf Schneckenjagd. TASPO: $6-7$.

DANKOWSKA E. 1991. Biologia i szkodliwość ślimaków nagich w szklarni i w tunelu. Mat. XXXI Sesji Nauk. IOR cz. II: 36-38.

DANKowska E. 1996. Harmfulness of Deroceras laeve (Müll.) and its control in greenhouse conditions. Roczniki Nauk Rolniczych, Seria E 25: 97-103.

DANKOWSKA E. 1998. Próby biologicznego zwalczania pomrowa walencjańskiego Lehmannia valentiana. Zeszyty Naukowe AR im. H. Kołłątaja w Krakowie 333: 809-810.

DANKOWSKA E., BARANOWSKI T. 1998. The slug pests of greenhouse ornamental plants. Zeszyty Problemowe Postępów Nauk Rolniczych w Lublinie 461: 171-176.

Like in experiment I, D. reticulatum was the most susceptible, and L. valentiana was not attacked.

In both experiments slugs infected with $P h$. hermaphrodita stopped feeding after three days, and characteristic swellings appeared on their mantles. In a week the slugs started dying.

The parasitic nematode Ph. hermaphrodita may be useful as a means of slug control, but not all slug species are equally susceptible to its invasion. Other slugs should be studied in this respect.

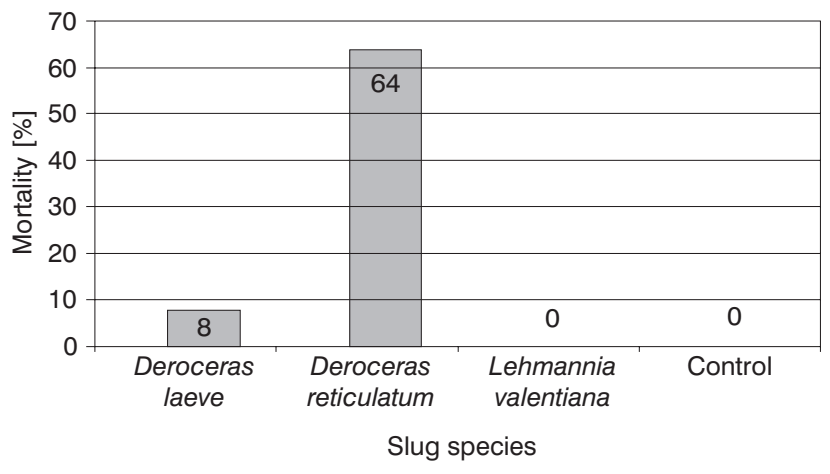

Fig. 2. The effect of Phasmarhabditis hermaphrodita applied to the soil (experiment II) on the slug mortality

TAN Li, GReWAL P. S. 2001. Pathogenicity of Moraxella osloensis, a bacterium associated with the nematode Phasmarhabditis hermaphrodita, to the slug Deroceras reticulatum. Appl. Environ. Microbiol. 67: 5010-5016.

Wilson M. J., Glen D. M., GEORGE S. K. 1993. The rhabditid nematode Phasmarhabditis hermaphrodita as a potential biological control agent for slugs. Biocontrol Science and Technology 3: 513-521.

Wilson M. J., Glen D. M., Hughes L. A., PeArCe J. D., RoDGERS P. B. 1994. Laboratory test of the potential of entomopathogenic nematodes for the control of field slugs (Deroceras reticulatum). J. Invertebr. Pathol. 64: 182-187.

Received: January 15th, 2006 Accepted: February 20th, 2006 